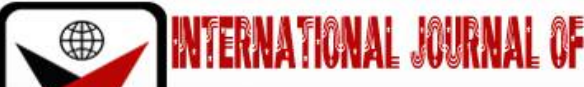

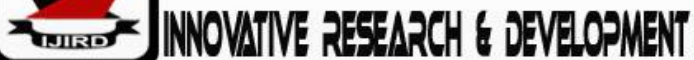

ISSN 2278-0211 (Online)

\section{Physically Challenged Persons and Selection of Fabrics: A Case Study in Sekondi-Takoradi Metropolis, Ghana}

\author{
Addo Mary Naa \\ Tutor, Department of Vocational Skills, Accra College of Education, Ghana \\ Amissah Emmanuel K. \\ Head, Department of Art Education, University of Education, Winneba, Ghana
}

\begin{abstract}
:
Clothing which is one of the basic needs of human being, plays a significant role in an individual's life at all stages. Physically challenged persons, however, are confronted with the choice of certain fabrics for clothing due to their disabilities. Evidence shows that two out of ten persons living in Ghana have problems with the right choice of textiles fabric for use as garment. The type of attire or article to which the people would like to use the fabric or cloth for remains unknown. This lack of data has been making it impossible for fashion designers and artisans to produce readyto-use articles and attires for the physically challenged persons. This study aims at assessing physically challenged persons and selection of textiles fabric for use considering the mobility gadget and its related comfortability among the physically challenged people in the Sekondi Takoradi-Metropolis. The research design used was descriptive and observation survey. An orderly sampling strategy was applied to select 300 respondents, comprising physically challenged cloth merchant, fashion designers and the public. Data for the study was obtained using structured questionnaires, interview and observation. The results of the study revealed that majority of the people in the formal sector like using the fabric for social function than any others. The findings indicated that two-thirds of the respondents who, to some extent, consider the durability of the textile's fabric in connection to the mobility gadget used but due to the low income earning it offset them to consider the price to durability. There was also a healthy relationship between patterns selection of textile fabric for garment and convenience of the mobility gadget. These findings provide a holistic understanding of the challenges physically challenged persons faced in the choice of fabrics for use considering the mobility gadget and its related comfortability. The study recommends that people should have positive mind towards the physically challenged and those with knowledge of fabric properties should assist them in the selection of good fabric to enhance their conditions.
\end{abstract}

Keywords: Physically challenged persons, choice of textiles fabric, garment, Sekondi-Takoradi metropolis, western region, Ghana

\section{Introduction}

Clothing which is one of the basic needs of human being, plays a significant role in an individual's life at all stages. Functional clothing and proper selection of textile in many cases can change the life of physically challenged people. Due to many reasons, they can't make choices. Unlike majority of people these class needs special attention. Retails stores are not also paying much attentions for these categories. Ghana enjoys a long tradition of custom-made clothing. The dry, savannah climate in the northern regions of the country is ideal for the cultivation of cotton, which is the primary material used by mills, weavers, batik and tie-dye manufactures in Ghana (Ghana Investment Promotion Centre (GIPC) 2008). Traditional apparel styles associated with Ghana include the kaba - fitted top, slit - fitted long skirt, boubou - loose embroidered garment, kaftan and fugu. The GIPC (2008) recognized contemporary designers, manufacturing western style such as trouser, suit, skirts suits, shirts, coats and jackets often incorporating indigenous African designs. Some clothing producers have provided some amounts of special attention by providing special functional requirements of clothing and textile products. For challenged people they need the thermal comfort properties as lying prolonged time in bed. Another common problem is the transmission of sweat from the skin. For certain parts, mechanical durability is another common problem. Evident shows that two out of ten persons living in Ghana have problems with the right choice of textiles fabric for use as garment. However, the type of attire or article to which the people would like to use the fabric for remains unknown. This is because there is no available study indicating the Ghanaian figure type and the knowledge on the fabric properties to aid the selection of particular textiles fabric that best suit the personality. This knowledge gap has made it impossible for fashion designers and artisans to produce ready-to-use articles and attires for the physically challenged people. Physically challenged people are therefore confronted with problems of choice of certain fabrics for attires due to their physical disabilities. Dressmakers and artisans are therefore not producing any useful information on the right properties of textiles fabrics to be used for the various grouping of the physically challenged. This study aims at assessing 
physically challenged persons and selection of fabric for use considering their mobility gadget and its related comfortability among the physically challenged people in the Sekondi Takoradi - Metropolis.

\section{Literature Review}

The clothing for the physically challenged persons often becomes a problem. Certain factors including personality and age, figure type, occasion and fashion as well as climate have been identified to be responsible for this phenomenon.

\subsection{Personality and Age}

As per Dutta (1997), selection of clothes should reflect wise investment of money as per their age, personality, climate etc. It also improves self-confidence (Carr and Pomery,1992).

\subsection{Figure Type}

Dresses should be selected as per figure type (Humphries,2004) not merely on the basis of latest trends in fashion. Selection of design and proper color based on figure type can camouflage or highlight features. Use of frills, piping in the dress makes look bulky (Weber,1997). Clothes with diagonal lines are appropriate for a tall and fat lady.

\subsection{Climate, Occasion and Fashion}

The main objective behind clothing is to maintain and protect body from temperature and adverse situation. This may sometimes leads to conflict between comfort and requirements (Sumrall, 2000). Occasion can be a reason behind selection (Darlene,1999). Parties, marriages and celebrations can be enjoyed with costly fabrics like brocade, and silken with bright and extravagant colours. Mourning or death generally comes with black, white or dull colours. Travel generally needs flexible, comfortable, smart and easily washable and sweat absorbing dresses. Day to day's work in houses demands old clothes with a risk of being spoiled. Persons love to follow latest trend in fashion in relation to colours, shapes and design generally fashionable by nature (Hollander,2003).

\subsection{Effects of Some Textiles Fabrics on the Physically Challenged Persons}

The quality of life for physically challenged and elderly people can in many cases be substantially improved by a better choice of good looking and functional clothing and other textile products. Clothing for the physically challenged should conceal or de-emphasize physical conditions that affect the shape of their bodies, while others choose to dress in a simpler and more revealing manner. Conformity is also some sort of a psychological shelter.

Physically challenged often lead to special functional requirements of clothing and other textile products in living environment. Persons with highly sensitive skin have to consider the skin contact or tactile properties and avoid clothing with hard seams. The wheelchair users require relatively low heat production as the thermal comfort properties of the fabric is important. Clothing should be selected to achieve the desired result, whatever it may be ignoring a physically challenged entirely and simply draping off-the-rack clothing over it is unlikely to be flattering, while adjusting it allows a personal statement to be made about the wearer's relationship with his physical condition. The transmission of moisture (sweat) from the skin is also a frequent problem. In addition, the mechanical durability of the materials in certain parts of the products can be a problem in many cases. A physically handicapped man wants to be remembered as an individual, but not as a visual impression. A strong personal style gives the viewer something to focus on other than the shape of the man's body, and allows the man to define himself on his own terms. It therefore reveals that the special finish giving to the fabric in the course of production can contribute positive or negative to the wearer.

\subsection{Categories of the Physically Challenged Persons}

Physically challenged is any restriction or lack (resulting from impairment) of ability to perform an activity in the manner or within the range considered normal for a human being (UN, 1983). According to Owusu-Banahene (2006) physically challenged is the orthopedic physically challenged as a category in special education. It refers to deformity in the person's leg or arms, twisting of neck, unusual raised shoulder, flat feet and congenital dislocation of the knee joint among other things. Physically challenged classification is the method used throughout the Paralympics movement to create and administer equitable athletic competitions. According to World Meaning of Archives (WMA). A wheelchair user is bounded to a person who has physically challenged that must permanently confine the person to the use of a wheelchair whiles mobility impaired is for those who cannot walk 200 feet without stopping to rest. It means the person cannot walk without the assistance of other person or walker, cane, crutches, braces, prosthetic device.

Erickson \& Lee (2008) also defined physically challenged as a person with a disability challenge that has any of the long lasting conditions that substantially limit one or more physical activities such as walking, climbing stairs, reaching, lifting or carrying. According to the IDEA (Individual with Physically challenged Education Act): physically challenged is also called orthopedic impairment. Orthopaedic impairment means a severe orthopedic impairment that adversely affects a child's educational performance. The term includes impairment caused by congenital anomaly, impairment cause by disease and impairment from other causes. Again, an amputee of the upper extremity is for those people who have amputation of at least one arm, hand or all five fingers. Visually impaired is for those people have impairment of visual function even after treatment and / or standard refractive correction and has visual acuity of equal to or less than 20/200 to light perception, or visual field of less than ten degrees from the point of fixation. 


\subsection{Clothing Specification for Physically Challenged Persons}

The individual requirements of physically challenged people regarding textiles and clothing are very much more diverse than for people without physically challenged. Persons with highly sensitive skin have to consider the skin contact or tactile properties and avoid clothing with hard seams (Weber, 1998). The thermal comfort properties are important for wheelchair users and for persons lying prolonged time in bed, with relatively low heat production. Werner (1999) in his book writes that the transmission of moisture (sweat) from the skin is also a frequent problem. Adolph (2000) highlighted that clothing should not cause any kind of discomfort in terms of thermal (insulation and breathability), tactile factors (hand properties), freedom of movement, pressure, no allergenic, etc.

\subsection{Sitting in a Wheelchair}

Although wheelchair users are fairly well served with special garments, still some need exists for individual needs. A major challenge is the price. More focused should be given on sitting posture. Both aesthetical and practical aspects like the body rise of trousers must be increased in the back and decreased in the front should be fulfilled. Light weight and less fabric should be given in the stomach area and exposure of the back area (Tyler, 2008). The leg length has to be adjusted according to the sitting posture. Sinclair (2001) talked about the importance of both functional and aesthetical properties. Owusu-Banahene (2006) highlighted the concept of durable clothing materials. Leaning against a table abrades the fabric in elbow areas. An optimum surface friction is needed for preventing sliding on the seat, and allowing the transfer from wheelchair to bed or to car seat. Wrinkling of fabric causes mainly aesthetical problems.

\subsection{Crutches and Other Supporting Devices}

Sometimes, design of clothing and choosing clothing materials take in to consideration about use of crutches, body-worn supports, prostheses and other supporting devices. Walking and moving cause's fabric abrasion against the devices and textiles can be exposed to severe abrasive forces. Enough space should be provided for arm movements. When walking with collators the hemlines may need compensating according to body position.

\subsection{Properties of Textiles Fabrics in Relation to the Comfort of the Physically Challenged Persons}

Simon \& Schuster (1999) had identified the following properties in textiles fabric, which in line enhances comfortability to the physically challenged.

First, cotton is a strong to very strong fibre and its strength increases when wet. Cotton is inelastic and this is responsible for the wrinkling and the creasing of cotton garments. This inelasticity also prevents fibres from returning to their original position, sometimes resulting in 'bagginess'. Cotton has good moisture absorbency, so is a comfortable fibre to wear. Cotton garments are dry-cleanable and machine washable. The researcher is of the view that these properties of cotton being strong will be very good for crutches users. Because of the devices they use, they usually get tears under their armpit and on the thighs of those who normally rub their hands on their thigh. As a result of that, it will require durable fabric. Second, woollen is a warm fibre to wear but can cause "prickly" skin due to the shape of the fibre, the more fine the wool the less prickle. Wool is a weak fibre, becoming weaker when wet and more easily distorted, so wash and dry with care. The elasticity of wool is very good, therefore good wrinkle recovery. Wool is the most absorbent fibre in common use, however causes woollen articles to dry slowly. Follow washing instructions on wool as it is prone to shrinking. Wool is a poor conductor of heat and a good insulator so is regarded as a warm fibre. The properties of wool provide warmth so it naturally good for wheelchair users in order to provide warmth. Third, silk is strong fibre but loses strength when wet, so must be laundered delicately. Only wash in cold or warm water at higher temperatures. Silk garments are dry-cleanable, Silk is cool to wear. The treatment of silk normally makes the yarns to pile out so with this is not good for a crutches user. Linen is a natural fibre from flax plant which is a very strong fibre. Its strength increases when wet. The inelasticity of flax is responsible for the wrinkling of linen fabrics. When wet, flax becomes even more inelastic and wrinkles more readily, a point to be watched during laundering. Fourth, polyester is man-made fibre from by-products of petrol manufacturing. Polyester is the most common manmade fibre. It can be a cheap fibre to produce and readily available therefore used often in cheaper garments. Polyester is a strong to very strong fibre, when wet fibres do not alter in strength. The elasticity of polyester fibres is good therefore making it very wrinkle resistant. Polyester may be regarded as non-absorbent, so is not considered a comfortable fibre to wear in warm weather. Polyester is a poor conductor of heat, so garments may be hot and clammy to wear and its non-absorbency can cause static electricity. Polyester is dry cleanable. Finally, viscose: viscose is a man-made regenerated cellulose fibre made from trees. Viscose can crease easily but is another cool fibre to wear. Viscose generally has a smooth, lustrous handle and quite good drape. Viscose has a fair strength but loses strength when wet, so care must be taken in laundering. Severe wringing should be avoided. It is a very absorbent fibre making it comfortable to wear. Viscose is dry cleanable.

\section{Materials and Methods}

The research design for the study was descriptive and observation survey. According to Gay (1992), all research studies involve data collection. Walled (1993) states that obtaining answers from a large group of people to a set of carefully designed and well administered questions lie at the heart of survey research. This is because it has the potential to provide a lot of information obtained from large group of individuals. Ekuri (1997) also asserts that descriptive survey involves the collection of data to accurately and objectively describe the status of existing phenomena. Based on the advantages of the descriptive survey, it was considered the most appropriate design for providing an overview of the physically challenged in the Sekondi-Takoradi Metropolis. Questionnaire was also designed and administered to select individuals to solicit their views on the subject under research. 
The study population frame includes fashion designers, physically challenged people and clothes dealers within the Sekondi-Takoradi Metropolis. To achieve optimum consensus, the researcher selected 200 respondents from the above groups for questionnaires. The sampling techniques adopted for the selection of the respondents were simple random and stratified random sampling. Observation, structured interview and semi-structured questionnaires were the instruments used for collecting the data. Information was collected on the selection of textiles fabric for garment for the physically challenged using the structured interview. The reasons for choosing observation as an instrument are the following: Using the observation gives the searchers the opportunity to interact with participants in the natural settings to see realities on the ground and determine the data to collect on them. According to Denseombe (2008), observation does not only rely on what people say, do or think but it also draws on the direct evidence of the eye to witness events first hand. Again, by employing observation, one can identify a problem by making an in-depth analysis of the problem. In addition, it is less demanding in nature, which makes it less bias in working abilities. Bell (2008) believes observation is useful in determining what people actually do or how they actually behave in their contents. It is therefore stems from the two assertion that observation approaches reality in its natural structure and studies event as they evolve. It also offers firsthand information without relying on the report of others. Eventually it is relatively inexpensive. Finally, the semi structured questionnaires were also used to collect data for the study. The questionnaires were open-ended type and this provides opportunity for respondents to respond in their own terms (Cohen et al, 2000).

\subsection{Data Collection Procedure}

The distribution of the structured interview was fairly done personally through interaction with the group concerned during the meeting to actually observe the realities on the ground and to expand to have in-depth knowledge on disabilities issues. The whole exercise was to welcome the idea and positive contribution and even gain some in-depth knowledge on other equally important information to enhance the research. The interaction was done in the local dialect for full participation. After their gathering, some of them voluntarily came for one on-one interaction. This exercise was followed by administration of the questionnaire to the 200 randomly selected respondents. The research team conducted the questionnaire administration. Quality control measures such as the need for independent completion of the questionnaires and freedom of participation or withdrawal from the study were strictly followed. Special efforts were also made to minimize methodological, personal and social desirability biases.

\section{Data Analysis}

Data analysis was conducted using SPSS Version 21.0 Statistical Package Program. Statistical tests used in data analysis were descriptive statistics, and percentages. The descriptive statistics was used to determine the frequency and percentage distribution of teachers' demographic characteristics. The data was presented in tables and figures generated by excel.

\section{Results} in Table 1.

This section presents the results of the data analyses. Respondents' demographic characteristics are summarized

\begin{tabular}{|c|c|c|c|c|c|}
\hline & & Frequency & Percent & $\begin{array}{c}\text { Valid } \\
\text { Percent }\end{array}$ & $\begin{array}{c}\text { Cumulative } \\
\text { Percent }\end{array}$ \\
\hline \multirow{2}{*}{ Valid } & Male & 24 & 57.1 & 60.0 & 60.0 \\
\cline { 2 - 6 } & Female & 16 & 38.1 & 40.0 & 100.0 \\
\cline { 2 - 6 } & Total & 40 & 95.2 & 100.0 & \\
\hline Missing & System & 2 & 4.8 & & \\
\hline \multicolumn{2}{|c|}{ Total } & 42 & 100.0 & & \\
\hline
\end{tabular}

Table 1: Demography on Gender

Data in Table 1 indicates that the males constitute the majority of the respondents (57.1\%).

\begin{tabular}{|c|c|c|c|c|c|}
\hline & & Frequency & Percent & Valid Percent & Cumulative Percent \\
\hline \multirow{3}{*}{ Valid } & Ok & 14 & 33.3 & 35.0 & 35.0 \\
\cline { 2 - 6 } & not bad & 15 & 35.7 & 37.5 & 12.5 \\
\cline { 2 - 6 } & Bad & 11 & 26.2 & 27.5 & 100.0 \\
\cline { 2 - 6 } & Total & 40 & 95.2 & 100.0 & \\
\hline Missing & System & 2 & 4.8 & & \\
\hline \multicolumn{2}{|c|}{ Total } & 42 & 100.0 & & \\
\hline
\end{tabular}

Table 2: Appearance of the Physically Challenged People

Data presented in Table 2 shows that $69.0 \%$ of the total respondents expressed positive sign that outwardly people with physical challenged dress neatly. 


\begin{tabular}{|c|c|c|c|c|c|}
\hline & & Frequency & Percent & Valid Percent & Cumulative Percent \\
\hline \multirow[t]{4}{*}{ Valid } & Male & 12 & 28.6 & 30.0 & 30.0 \\
\hline & Female & 9 & 21.4 & 22.5 & 52.5 \\
\hline & Both & 19 & 45.2 & 47.5 & 100.0 \\
\hline & Total & 40 & 95.2 & 100.0 & \\
\hline Missing & System & 2 & 4.8 & & \\
\hline \multicolumn{2}{|c|}{ Total } & 42 & 100.0 & & \\
\hline
\end{tabular}

Table 3: Service Patronage

Data outlined in Table 3 revealed that close to half of the respondents (45.2\%) highly patronize the service from cloth dealer and the fashion designers.

\begin{tabular}{|c|c|c|c|c|c|}
\hline & & Frequency & Percent & Valid Percent & Cumulative Percent \\
\hline \multirow{3}{*}{ Valid } & Male & 9 & 21.4 & 22.5 & 22.5 \\
\cline { 2 - 6 } & Female & 17 & 40.5 & 42.5 & 65.0 \\
\cline { 2 - 6 } & both sex & 14 & 33.3 & 35.0 & 100.0 \\
\cline { 2 - 6 } & Total & 40 & 95.2 & 100.0 & \\
\hline Missing & System & 2 & 4.8 & & \\
\hline \multicolumn{2}{|c|}{ Total } & 42 & 100.0 & & \\
\hline
\end{tabular}

Table 4: Understanding of Personal Grooming

In Table 4, the analysis revealed that physically challenged female attached more importance to personal grooming (42.5\%) than their male counterpart (22.5\%).

\begin{tabular}{|c|c|c|c|c|c|}
\hline & & Frequency & Percent & Valid Percent & Cumulative Percent \\
\hline \multirow[t]{3}{*}{ Valid } & yes & 28 & 62.6 & 65.0 & 50.0 \\
\hline & no & 12 & 28.6 & 35.0 & 100.0 \\
\hline & Total & 40 & 95.2 & 100.0 & \\
\hline Missing & System & 2 & 4.8 & & \\
\hline \multicolumn{2}{|c|}{ Total } & 42 & 100.0 & & \\
\hline
\end{tabular}

Table 5: Admiration of the Dress of Physically Challenged Persons

Issue on whether people do admire the dressing of the physically challenged people, Data in Table $\mathbf{5}$ indicates that over $62 \%$ of the total respondents admire persons with physically challenged who are neatly dressed.

\begin{tabular}{|c|c|c|c|c|c|}
\hline & & Frequency & Percent & Valid Percent & Cumulative Percent \\
\hline \multirow{4}{*}{ Valid } & Colour & 9 & 21.4 & 22.5 & 22.5 \\
\cline { 2 - 6 } & Style & 10 & 23.8 & 25.0 & 47.5 \\
\cline { 2 - 6 } & Fitness & 10 & 23.8 & 25.0 & 72.5 \\
\cline { 2 - 5 } & Personality & 5 & 11.9 & 12.5 & 85.0 \\
\cline { 2 - 6 } & choice of fabric & 6 & 14.3 & 15.0 & 100.0 \\
\cline { 2 - 6 } & Total & 40 & 95.2 & 100.0 & \\
\hline Missing & System & 2 & 4.8 & & \\
\hline \multicolumn{2}{|c|}{ Total } & 42 & 100.0 & & \\
\hline
\end{tabular}

Table 6: Points of Good Grooming

Table 6 shows that majority of the respondents considered the style and fitness of the garments as the most important factors that enhance the total beauty of one's personal good grooming.

\begin{tabular}{|c|c|c|c|c|c|}
\hline & & Frequency & Percent & Valid Percent & Cumulative Percent \\
\hline \multirow{3}{*}{ Valid } & Yes & 37 & 59.7 & 63.8 & 63.8 \\
\cline { 2 - 6 } & No & 21 & 33.9 & 36.2 & 100.0 \\
\cline { 2 - 6 } & Total & 58 & 93.5 & 100.0 & \\
\hline Missing & System & 4 & 6.5 & & \\
\hline \multicolumn{2}{|c|}{ Total } & 62 & 100.0 & & \\
\hline
\end{tabular}

Table 7: Advice to the Physically Challenged Persons

Data presented in Table 7 greater number of respondents (63.8\%) do advice their physically challenged clients about the choice of appropriate style. 


\begin{tabular}{|c|c|c|c|c|c|}
\hline & & Frequency & Percent & Valid Percent & Cumulative Percent \\
\hline \multirow{7}{*}{ Valid } & strongly agree & 31 & 50.0 & 53.4 & 53.4 \\
\cline { 2 - 6 } & Agree & 19 & 30.6 & 32.8 & 86.2 \\
\cline { 2 - 6 } & disagree & 8 & 12.9 & 13.8 & 100.0 \\
\cline { 2 - 6 } & Total & 58 & 93.5 & 100.0 & \\
\hline Missing & System & 4 & 6.5 & & \\
\hline \multicolumn{2}{|c|}{ Total } & 62 & 100.0 & & \\
\hline
\end{tabular}

Table 9: Selection of Textiles Pattern is Time Consuming

Data displayed in Table 9 suggests that more than two-third of respondents(86.2\%) view careful selection of textiles pattern as the most source of beauty to the entire appearance of the person with physically challenged.

\begin{tabular}{|c|c|c|c|c|c|}
\hline & & Frequency & Percent & Valid Percent & Cumulative Percent \\
\hline \multirow{3}{*}{ Valid } & $18-25$ & 21 & 32.8 & 35.0 & 35.0 \\
\cline { 2 - 6 } & $26-30$ & 21 & 32.8 & 35.0 & 70.0 \\
\cline { 2 - 6 } & $31-35$ & 11 & 17.2 & 18.3 & 88.3 \\
\cline { 2 - 6 } & 36 and above & 7 & 10.9 & 11.7 & 100.0 \\
\cline { 2 - 6 } & Total & 60 & 93.8 & 100.0 & \\
\hline Missing & System & 4 & 6.2 & & \\
\hline \multicolumn{2}{|r|}{} & 64 & 100.0 & & \\
\hline
\end{tabular}

Table 10: Age Group

The data recorded in Table 10 suggests that the most influential group of the physically challenge persons who are more concern with the selection of the textiles fabric were in the age range of between 18- 30 (70\%).

\begin{tabular}{|c|c|c|c|c|c|}
\hline & & Frequency & Percent & Valid Percent & Cumulative Percent \\
\hline \multirow{4}{*}{ Valid } & Wheelchair user & 18 & 28.1 & 30.0 & 30.0 \\
\cline { 2 - 6 } & Crutches user & 22 & 34.4 & 36.7 & 66.7 \\
\cline { 2 - 6 } & Crawling & 20 & 31.2 & 33.3 & 100.0 \\
\cline { 2 - 6 } & Total & 60 & 93.8 & 100.0 & \\
\hline Missing & System & 4 & 6.2 & & \\
\hline \multicolumn{7}{|c|}{} & 64 & 100.0 & & \\
\hline
\end{tabular}

Table 11: Type of Physically Challenged Persons

The data presented in Table 11 shows that majority of the physically challenged persons were crutched users (36.7\%).

\begin{tabular}{|c|c|c|c|c|c|}
\hline & & Frequency & Percent & Valid Percent & Cumulative Percent \\
\hline \multirow[t]{3}{*}{ Valid } & Male & 24 & 37.5 & 40.0 & 40.0 \\
\hline & Female & 35 & 54.7 & 58.3 & 98.3 \\
\hline & Total & 60 & 93.8 & 100.0 & \\
\hline Missing & System & 4 & 6.2 & & \\
\hline \multicolumn{2}{|c|}{ Total } & 64 & 100.0 & & \\
\hline
\end{tabular}

Table 12: Gender

\begin{tabular}{|c|c|c|c|c|c|}
\hline \multicolumn{2}{|c|}{ Response Formats } & Frequency & Percent & Valid Percent & Cumulative Percent \\
\hline \multirow{3}{*}{ Valid } & $\begin{array}{c}\text { Basic } \\
\text { Education }\end{array}$ & 17 & 16.7 & 17.0 & 17.0 \\
\cline { 2 - 6 } & Secondary & 55 & 53.9 & 55.0 & 72.0 \\
\cline { 2 - 6 } & Tertiary level & 23 & 22.5 & 23.0 & 95.0 \\
\cline { 2 - 6 } & Vocational & 5 & 4.9 & 5.0 & 100.0 \\
\cline { 2 - 6 } & Total & 100 & 98.0 & 100.0 & \\
\hline Missing & System & 2 & 2.0 & & \\
\hline \multicolumn{2}{|c|}{} & 102 & 100.0 & & \\
\hline
\end{tabular}

Table 13: Educational Level of Physically Challenged Persons 
Data in Table 13 indicates that there was positive significant association between educational level and grooming practice in the selection of textile fabric. It shows that much importance of the respondents was on higher level of education than those with lower level of education.

\begin{tabular}{|c|c|c|c|c|c|}
\hline $\begin{array}{c}\text { Response } \\
\text { Formats }\end{array}$ & Frequency & Percent & $\begin{array}{c}\text { Valid } \\
\text { Percent }\end{array}$ & Cumulative Percent \\
\hline \multirow{4}{*}{ Valid } & Strongly agree & 43 & 42.2 & 43.0 & 43.0 \\
\cline { 2 - 6 } & Agree & 29 & 28.4 & 29.0 & 72.0 \\
\cline { 2 - 6 } & No idea & 11 & 10.8 & 11.0 & 83.0 \\
\cline { 2 - 6 } & Disagree & 14 & 13.7 & 14.0 & 97.0 \\
\cline { 2 - 6 } & Strongly disagree & 3 & 2.9 & 3.0 & 100.0 \\
\cline { 2 - 6 } & Total & 100 & 98.0 & 100.0 & \\
\hline Missing & System & $\mathbf{2}$ & 2.0 & & \\
\hline \multicolumn{2}{|c|}{} & 102 & 100.0 & & \\
\hline
\end{tabular}

Table 14: Knowledge on Good Selection of Textiles Pattern Boost Your Confidence Level

Table 14 data indicates that greater number of respondents $(72.0 \%)$ expressed that knowledge on good selection of textiles pattern boost ones confidence and for that matter person with physically challenged.

\begin{tabular}{|c|c|c|c|c|c|}
\hline \multicolumn{2}{|c|}{ Response Formats } & Frequency & Percent & $\begin{array}{c}\text { Valid } \\
\text { Percent }\end{array}$ & Cumulative Percent \\
\hline \multirow{3}{*}{ Valid } & strongly agree & 23 & 37.1 & 39.7 & 39.7 \\
\cline { 2 - 6 } & Agree & 26 & 41.9 & 44.8 & 84.5 \\
\cline { 2 - 6 } & disagree & 9 & 14.5 & 15.5 & 100.0 \\
\cline { 2 - 6 } & Total & 58 & 93.5 & 100.0 & \\
\hline Missing & System & 4 & 6.5 & & \\
\hline \multicolumn{2}{|c|}{ Total } & 62 & 100.0 & & \\
\hline
\end{tabular}

Table 15: Fabric Can Make Your Condition More Uncomfortable

The data captured in Table 15 suggests that more than two thirds of the respondents (44.8\%) expressed the view that wrong selection of textiles fabric contribute negatively to the comfortability of the physical condition.

\begin{tabular}{|c|c|c|c|c|c|}
\hline \multicolumn{6}{|c|}{ Paired Samples Statistics } \\
\hline & & Mean & $\mathrm{N}$ & Std. Deviation & Std. Error Mean \\
\hline \multirow[t]{2}{*}{ Pair 1} & $\begin{array}{l}\text { People really admired well- } \\
\text { groomed person. }\end{array}$ & 1.95 & 60 & 1.064 & .137 \\
\hline & $\begin{array}{l}\text { Physically challenged persons are } \\
\text { more admired than their other } \\
\text { counterparts do. }\end{array}$ & 2.78 & 60 & 1.439 & .186 \\
\hline
\end{tabular}

Table 16: Admiration of Physically Challenged Persons

Data presented in Table 16 represents the level of importance people attach to persons with physically challenged. The data indicates that physically challenged persons are more admired than their able counterparts because of their grooming practice. Difference in means $=(95 \% \mathrm{CI}: 1.95$ to 2.78$)$.

\begin{tabular}{|c|c|c|c|c|c|}
\hline \multicolumn{6}{|c|}{ Do you know that as a physically Challenged, you are good grooming practice attract people to your } \\
side?
\end{tabular}

Table 17: Attraction of the Physically Challenged Persons 
The study discovered that physically challenged people are often attracted by their way of dressing as majority of the respondents constituting seventy-two point zero. Percent $(72.0 \%)$ attest to the fact that they often attracted by the way people with physically challenged dressed.

\begin{tabular}{|c|c|c|c|c|c|}
\hline \multicolumn{6}{|c|}{$\begin{array}{c}\text { Good Selection of Textiles Pattern Add Beauty to Entire Appearance of } \\
\text { Physically Challenged Persons }\end{array}$} \\
\hline \multicolumn{2}{|c|}{ Response Formats } & Frequency & Percent & Valid & Cumulative \\
\hline \multirow[t]{6}{*}{ Valid } & Strongly agree & 34 & 33.3 & 34.0 & 34.0 \\
\hline & Agree & 39 & 38.2 & 39.0 & 73.0 \\
\hline & No idea & 17 & 16.7 & 17.0 & 90.0 \\
\hline & Strongly agree & 9 & 8.8 & 9.0 & 99.0 \\
\hline & Disagree & 1 & 1.0 & 1.0 & 100.0 \\
\hline & Total & 100 & 98.0 & 100.0 & \\
\hline Missing & System & 2 & 2.0 & & \\
\hline \multicolumn{2}{|r|}{ Total } & 102 & 100.0 & & \\
\hline
\end{tabular}

Table 18: Choice of Pattern in Textiles

The study discovered that physically challenged people measured the patterns in the textiles fabric as being important. Strongly agree (34\%), Agree (39\%) were the two key information needed to make right choice of textiles pattern in the fabric consumers considered most important as displayed in Table 18.

\begin{tabular}{|c|c|c|c|c|c|}
\hline \multicolumn{2}{|c|}{ Response Formats } & Frequency & Percent & Valid Percent & Cumulative Percent \\
\hline \multirow{4}{*}{ Valid } & & & & & 46.0 \\
\cline { 2 - 6 } & Price & 46 & 45.1 & 46.0 & 73.0 \\
\cline { 2 - 6 } & Design & 27 & 26.5 & 27.0 & 91.0 \\
\cline { 2 - 6 } & Quality & 18 & 17.6 & 18.0 & 100.0 \\
\cline { 2 - 6 } & Purpose & 9 & 8.8 & 9.0 & \\
\cline { 2 - 6 } & Total & 100 & 98.0 & 100.0 & \\
\hline Missing & System & 2 & 2.0 & & \\
\hline \multicolumn{2}{|c|}{ Total } & 102 & 100.0 & & \\
\hline
\end{tabular}

Table 19: What Do You Consider Before Buying The Textiles Fabric?

Data presented in Table 19 suggests that majority of the respondents $(46.0 \%)$ attached more importance to the price of products. Those who consider the purpose before making any purchase were the least on the record (9.0\%).

\begin{tabular}{|c|c|c|c|c|c|}
\hline \multicolumn{2}{|c|}{ Response Formats } & Frequency & Percent & Valid Percent & Cumulative Percent \\
\hline \multirow[t]{4}{*}{ Valid } & Ok & 23 & 37.1 & 39.7 & 39.7 \\
\hline & Sad & 16 & 25.8 & 27.6 & 67.2 \\
\hline & Happy & 19 & 30.6 & 32.8 & 100.0 \\
\hline & Total & 58 & 93.5 & 100.0 & \\
\hline Missing & System & 4 & 6.5 & & \\
\hline \multicolumn{2}{|c|}{ Total } & 62 & 100.0 & & \\
\hline
\end{tabular}

Table 20: Reaction with the Physically Challenged Persons

Table 20 data indicates the analysis of comparisons between the clients and the service provider. This results show that service providers interact with their client, but in most of the cases, the advice given to the physically challenged concerning their good grooming is been felt in a different contest and as a result might loss the customer.

\begin{tabular}{|c|c|c|c|c|c|}
\hline \multicolumn{2}{|c|}{ Response Formats } & Frequency & Percent & $\begin{array}{c}\text { Valid } \\
\text { Percent }\end{array}$ & $\begin{array}{c}\text { Cumulative } \\
\text { Percent }\end{array}$ \\
\hline \multirow{3}{*}{ Valid } & & & & & \\
\cline { 2 - 6 } & Good Finishes & 41 & 16.4 & 20.6 & 20.6 \\
\cline { 2 - 6 } & Good stitches & 62 & 24.8 & 31.2 & 51.8 \\
\cline { 2 - 6 } & Choice of style & 65 & 26.0 & 32.7 & 84.4 \\
\cline { 2 - 6 } & Customer relation & 31 & 12.4 & 15.6 & 100.0 \\
\hline Missing & Total & 199 & 79.6 & 100.0 & \\
\hline \multicolumn{2}{|c|}{ System } & 51 & 20.4 & & \\
\hline
\end{tabular}

Table 21: Customers Desire 
The study seeks to find out the kind of garment mostly sewn by the physically challenged. The results show that customers measured all the processes involve in sewing as being important. Choice of style (32.7\%), good stitching (31.2 $\%)$, were the key information customers considered most important. The data shows that customer is more concern with the right interpretation of the chosen style in conformity with the client's figure structure in relation to the type of their physically challenged before they check the stitches. It therefore implies that weather a service provider will be able to maintain a client to a long time will greatly depend on the choice of style considering the clients figure fault.

\begin{tabular}{|c|c|c|c|c|c|}
\hline \multicolumn{2}{|c|}{ Response Formats } & Frequency & Percent & $\begin{array}{c}\text { Valid } \\
\text { Percent }\end{array}$ & $\begin{array}{c}\text { Cumulative } \\
\text { Percent }\end{array}$ \\
\hline \multirow{3}{*}{ Valid } & Magazine & 38 & 15.2 & 19.0 & 19.0 \\
\cline { 2 - 6 } & Catalogue & 64 & 25.6 & 32.0 & 51.0 \\
\cline { 2 - 6 } & Sketches & 75 & 30.0 & 37.5 & 88.5 \\
\cline { 2 - 6 } & style sample & 23 & 9.2 & 11.5 & 100.0 \\
\cline { 2 - 6 } & Total & 200 & 80.0 & 100.0 & \\
\hline Missing & System & 50 & 20.0 & & \\
\hline \multicolumn{2}{|c|}{ Total } & 250 & 100.0 & & \\
\hline
\end{tabular}

Table 22: Sources of Styles

Source of inspiration for the designers has been tabulated in Table 22. It became known that close to three quarter of the total respondents (88.5\%) prefer sketching their styles for the service providers to sew for them.

\begin{tabular}{|c|c|c|c|c|c|}
\hline \multicolumn{2}{|c|}{ Response Formats } & Frequency & Percent & Valid Percent & Cumulative Percent \\
\hline \multirow[t]{3}{*}{ Valid } & Yes & 31 & 12.0 & 13.8 & 52.5 \\
\hline & No & 169 & 78.0 & 79.5 & 100.0 \\
\hline & Total & 200 & 80.0 & 100.0 & \\
\hline Missing & System & 50 & 20.0 & & \\
\hline \multicolumn{2}{|c|}{ Total } & 250 & 100.0 & & \\
\hline
\end{tabular}

Table 23: - Awareness of Figure Faults

The analysis of whether people understand figure fault, which will enable them to make right choices in the selection of a particular style, almost all the respondents, responded that, they are aware of their figure fault. More than two thirds of the respondents do not know their figure type description representing 78\% of the total respondents. Table

\begin{tabular}{|l|l|l|l|l|l|}
\hline \multicolumn{2}{|l|}{ Response Formats } & Frequency & Percent & Valid Percent & Cumulative Percent \\
\hline Valid & $\begin{array}{l}\text { Basic } \\
\text { Education }\end{array}$ & 25 & 40.3 & 43.1 & 43.1 \\
\cline { 2 - 6 } & Secondary & 17 & 27.4 & 29.0 & 72.4 \\
\cline { 2 - 6 } & Tertiary level & 9 & 14.5 & 15.5 & 87.9 \\
\cline { 2 - 6 } & Vocational & 7 & 11.3 & 12.1 & 100.0 \\
\cline { 2 - 6 } & Total & 100 & 98.0 & 100.0 & \\
\hline Missing & System & 2 & 2.0 & & \\
\hline Total & $\mathbf{1 0 2}$ & $\mathbf{1 0 0 . 0}$ & & \\
\hline
\end{tabular}

Table 24: Educational Level of the Fashion Designers and Cloth Dealers

Evidently, Table 24 data revealed that close to half of the respondents (43.1\%) had attained cast in the basic educational level. The average respondents who had attained their Secondary education represented by valid percentage of twentynine points zero percent (29.0\%), while one those who had vocational education were the least on the rank. Further interview with the respondents asserts that, majority of the respondents were the self-employed and were representing fifty two point five percent $(52.5 \%)$.

\section{Discussion}

Disabilities often lead to special fabric requirement for everyday living activities. This research aims to identify problems associated with the selection of textiles fabric as garment for the physically challenged persons and come out with a guideline concerning the kind of fabric that can best assist the physically challenged peoples to select textiles fabric that complement well with their mobility gadget use in their day-to-day activities. It also aims at creating awareness for designers and cloth merchant with the needed information that can facilitate them to sell required fabric properties for the physically challenged.

\subsection{Findings from the Physically Challenged Persons}

The results show that majority of the physically challenged persons are youth within the age bracket of 15-35 years. The greater proportion of this population affirm that, in most cases, they select the textiles fabric for clothing based on its affordability and in-built patterns. This suggests that they do not consider their physique or figure types before purchasing their fabric. This could affect their personality appearance and comfortability. Clothing is an essential part of 
our appearance, and with the choice of clothing, we show a part of our personality. We generally prefer different types of clothing for different types of activities (leisure, work, parties, etc). Properly designed clothing can act as camouflage hiding possible disabilities. The physically challenged persons therefore needed adequate education on the choice of the right fabrics based on their figure types and the role of fabric designers and dressmakers, particularly those who sewn dresses for the physically challenged persons cannot be overemphasized.

\subsection{Views of Fashion Designers and Cloth Dealers}

Varieties of fabrics are available in the market today ranging from natural to regenerated and synthetic. While selecting fabric for the physically challenged persons, comfort and mobility should be the first concern and aesthetics to be the second. The input from the questionnaires sent to the cloth dealers suggest that physically challenged persons consider the price of the items first before making any purchase.

It further adds that cotton is the fabric of choice for any form of disability or for chronic diseases patients. Cotton is available in so many forms that one can easily select according to the requirements but because of the price, they prefer to buy synthetic materials that are more affordable. The most important property of cotton is that it is very comfortable to wear and durable to care. Cotton flannelette is one form of cotton, which is soft, durable and warm. It is suitable for people who need clothes that are warmer and softer. People with paralysis or immobility should wear clothes made up of cotton/polyester blended fabric. Cotton polyester blend is soft, easy to iron, stain resistant, easy to wash and soil repellent too.

Responses from the fashion designers had it that most of the physically challenged persons prefer to sketch their own design to be sewn for them. They hardly pick their style from the catalogue or magazine. Further interview with the fashion designers suggest that there should be dress guideline to assist persons with physically challenged select style based on their conditions. For instance, wheelchair users who may have lots of long jackets and tunics but find that while sitting, the fabric bunched up around hips and waist, we offer cut out backs which eliminate sitting on excess fabric. This implies that there was positive but significantly weak association between the levels of respondents and the knowledge of textiles pattern in relation to the selection of specific fabric for garment. As it reflected in the ratio .154: .001, .108: .021, $.166: 000$ and 118:.012 respectively.

It indicates that there was positive significant association between educational level and rightful selection of textiles pattern. Thus ( $\mathrm{rs}=.101, \mathrm{p}<032$ ). This showed that much important of the respondent was on higher level of education on price, colour, weather, than those with lower level of importance on the knowledge of the fabric properties. This indicates that respondents who earn higher monthly income attached much importance to personal grooming practice than respondents with less monthly income.

There is a moderate but strong association between the age of the Physically Challenged and the knowledge of fabric properties $(r s=0.30, p=0.674)$. This shows that physically challenged who are older attach much importance to the properties of textiles fabric than those younger. There was no significant association between physically challenge and the selection of colour of textiles fabric for garment to report.

On the educational background of the fashion designers, the research was found to be composed of mainly basic education level, which accounts for $72.1 \%$ of the total respondents are sample for the study. The lowest representation was respondents having secondary level education and the uneducated, which constitute $3.5 \%$ and $4.0 \%$ respectively. This shows that, people with basic education certificate who have obtained some knowledge on the properties of textiles fabric mainly dominate the study.

It also shows clearly that, most of the respondents highly check the price of the items before they purchase. Apart from the price, the next most influence factor was the design in the fabric and this was rated highest (88.1\%) which indicate it to be important or very important. Others such as properties, uses, whether, laundry and convenience were all found to be influential factors for buying behaviour of respondents.

The comparison of level of importance recorded a number of significant differences for the gender to the properties of the fabric quality. This indicates that the level of importance of fabric properties to respondents does not depend on gender. All of the significant values from the fabric properties were more than 0.05 indicating they are all concerned about quality of fabric properties equality with no gender prejudice to the level of importance on the fabric properties information.

\section{Conclusions}

The study assessed the selection of textiles fabric for use considering the mobility gadget and its related comfortability among the physically challenged persons in the Sekondi Takoradi-Metropolis. The results of the study showed that the educational level of physically challenged persons appeared to influence the selection they attached to the textiles fabric properties. Although more than half of the consumers had attained basic education, they were concerned about durability as textiles fabric properties. The study also revealed that physically challenged persons pay importance attention to the prices and the designs in the textile fabrics before making any purchase. The textiles fabric properties, however, do not depend on gender variabilities.

Considering the choice of the textiles fabric for use as garment for the physically challenged persons, it was evident that the wrong choice of textiles pattern can emphasis one is physically challenged. This has positive but significantly weak association with the income level of the respondent. However, no statistically significant associations were found between all the other factors that influence buying behaviour and income level. Finally, the results of the study revealed that high-income earners are more concerned with textiles fabric property information than less income earners. 
The most important duty of the outerwear is to be a part of the personal image, and therefore the choice of clothing is very individual and will depend on the wear situation.

\section{Recommendations}

Based on the findings of the study, the following are recommendations to enhance effective selection of textiles fabric for use considering the mobility gadget and its related comfortability among the physically challenged persons. First, persons with physically challenged need more education to guide them make informed decision as to the fabric properties that has bearing with their mobility gadget and comfortability. Putting this measures in place will boost confidence of the physically challenged persons to ensure high recognition of the made in Ghana products. Second, periodically, physically challenged people should be given educational talk on the properties of textiles fabric and the factors that should influence the selection of a particular textile's fabric for garment. Third, physically challenges people can improve their life quality through a better choice in clothing. So, it can be said that physically challenged people need special requirement in terms of clothing selection.

\section{Conflict of Interest}

The authors declare no potential conflicts of interests.

\section{References}

i. Adolph, G. (2000). Educational Research, All good Books Ltd, Accra North, Ghana.

ii. Bell, H. (2008). Cognitive Psychology and Its Implications. Second Edition. New York.

iii. Carr, M. \& Pomery, S. (1992). Fashion Design and Product Development, Blackwell Science Ltd.

iv. Cohen Et Al (2000). Research Methods in Education. New York, N.Y Rutledge

v. Darlene R. (1999)._Style, Blackwell Scientific Publication, Netherlands.

vi. David, J. T. (2008). Revised Technology of clothing manufacture.4 $4^{\text {th }}$ edition Blackwell Publishing Ltd, USA

vii. Denseombe, M. (2008). The Art of Research: Art Teachers Affinity with Ethnography.

viii. Dutta, F. (1997). Textiles Science, West Publishing Company, U.S.A.

ix. Ekuri, Y. (1997). Special Disabilities, Samang Publishers, Accra- Ghana.

X. Gay, M. (1992). Needlework for schools. Black and sons Ltd. Nigerian edition by Wangement.

xi. Hollander, W. (2003). Self Confidence, Macmillan Education Limited, London.

xii. IDEA (Individual with Physically challenged Education Act): UN, 1983.

xiii. Jeanet, W. (1997). Clothing. McGraw-Hill publishing Company, U.S.A.

xiv. Kadolph, S.J. \& Langford, A.L. (2002). Textiles .9th Ed. Upper Saddle River, New Jersey. Pearson Education.

xv. Liddell, L. A. (1997). Cloth and your Appearance, Good Heart Will, Coxco Inc. New York.

xvi. Owusu- Banahene, N. (2006). Fundamental Issues in Special Education, Wilas publishing Co. Kumasi Ghana.

xvii. Ploit, M. (1995). How to Design and Evaluate Research in Education, McGraw - HillInc. New York.

xviii. Rose, S. (2001). ICT Activities for textiles technology. Divisional of Reed Education and professional Publishing Ltd / Heinemann Educational Publishers. Fairchild Publishers, New York.

xix. Sara J., Kadolph, R. and Anna L. L. (1998). Textiles, Eighth edition upper Saddle River, New Jersey Columbus, Obio.

xx. Simon, T. \&Schuster, K. (1999). Textile Preparation and Dyeing. Science Publishers, U.S.A.

xxi. Sumrall, M. (2000). Technology of Textile Properties. Chas Bennet Co, Inc Peoria, IIIionois. New York.

xxii. Walled, S. (1993). Home Management for Schools and Colleges. Africana-top Publisher Ltd. Lagos-Nigeria.

xxiii. Werner (1999). Introduction to Design in the Fashion. Adom Publishing Ltd. Cape Coast-Ghana. 